\title{
Application of Special Risk Reduction Protective Measures in Combiterminals for Dangerous Goods
}

\author{
CIMER Zsolt, ${ }^{1}$ VARGA Ferenc ${ }^{2}$
}

\begin{abstract}
During the combined transport of dangerous goods, in the territory of combiterminals, transport takes place from one type of transport to another means of transport. During the trans-shipment and the temporary storage of hazardous materials accidents resulting in smaller or larger consequences may occur (and in recent times have occurred as well). Experience has shown that reducing the consequences of such accidents requires the use of some special tools. In our article we present these tools in order to reduce such consequences as well as the technical foundations of their applicability.
\end{abstract}

Keywords: combiterminals, disaster management, major accidents involving dangerous substances, device system, technical tools

\section{Combiterminals for Dangerous Goods}

The transportation of dangerous goods - similarly to any other goods - is mainly carried out in a simple way: involving only one mode of transport. In the course of combined (or multimodal) transportation, the transportation task is carried out with the participation of two or more transport modes. Due to the cooperation of different modes of transport in the course of combined goods transportation and establishment of shipment chains, the advantages of each transport mode can be combined while eliminating the disadvantages. Combined transportation can contribute to the reduction of the deterioration of public roads, public traffic jams as well as environmental polluting effects. Such combined transportation requires an intermodal transport unit (e.g. containers), which have to be moved between the different transport modes. In the course of combined transportation the so-called intermodal transport unit containing the goods is moved with the help of special loading equipment. The movement of unit cargo, i.e. the loading from one vehicle to another is carried out in the combiterminals. [1] [2]

1 Szent István University, Institute of Fire Safety and Disaster Management; e-mail: cimer.zsolt@ybl.szie.hu

2 Budapest Disaster Management Directorate, e-mail: ferenc.varga@katved.gov.hu 


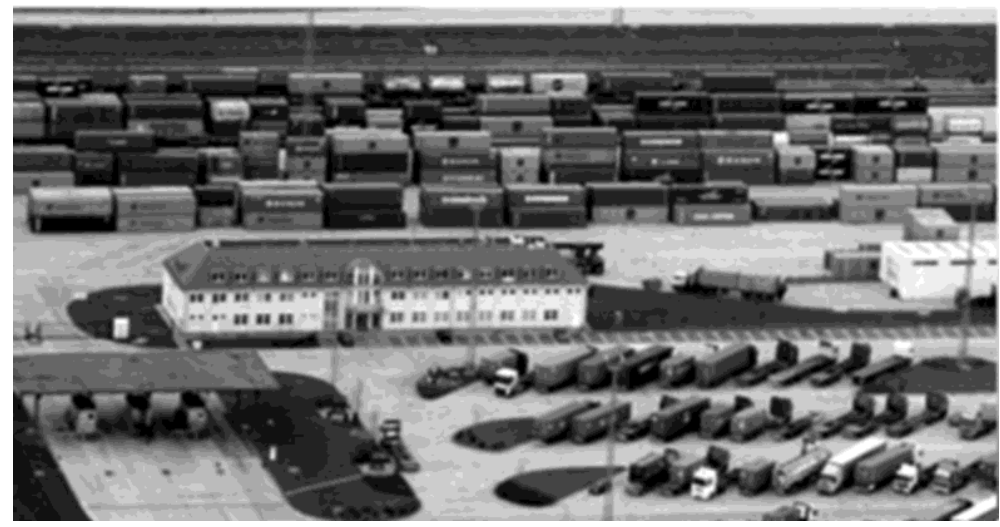

Picture 1. View of a combined terminal. [3]

The reloading between means of transport in the combined terminals can be carried out by cranes or loading machines.

In case of cranes the rail stands on the ground and the crane structure forms a frame. One of the vertical pillars of the crane is fixed while the other is hinge-joined to the bridge so that the structure is statically determinate, i.e. it does not hinder thermal expansion. Cranes mainly move on special heavy-duty rails, alongside the loading rail-tracks.

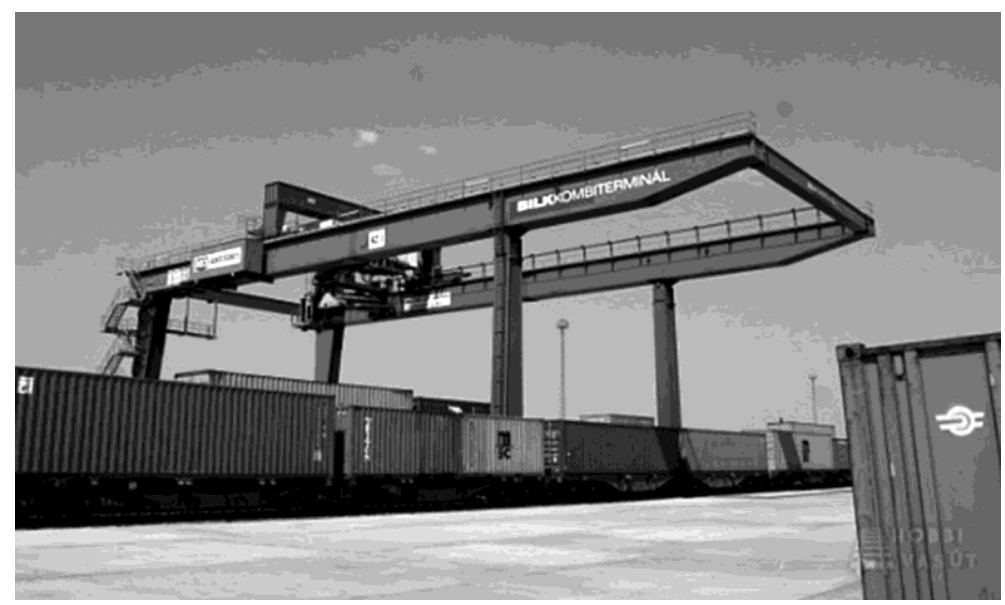

Picture 2. Crane. [3]

Every fifth container in the world is moved by Kalmar loaders. These machines are equipped with special frames and are designed to move empty and loaded containers in port terminals. They are special advanced loading machines developed from fork lift trucks with a container holding frame in the place of the fork cart, which holds the loaded container at its four corners. The frame is adjustable; therefore it is not only able to lift $12 \mathrm{~m}$ containers, but also $6.1 \mathrm{~m}$ and $9.1 \mathrm{~m}$ containers. [4] In the below picture a Kalmar loader is lifting a so-called tanktainer (a tank container) from a lorry. 


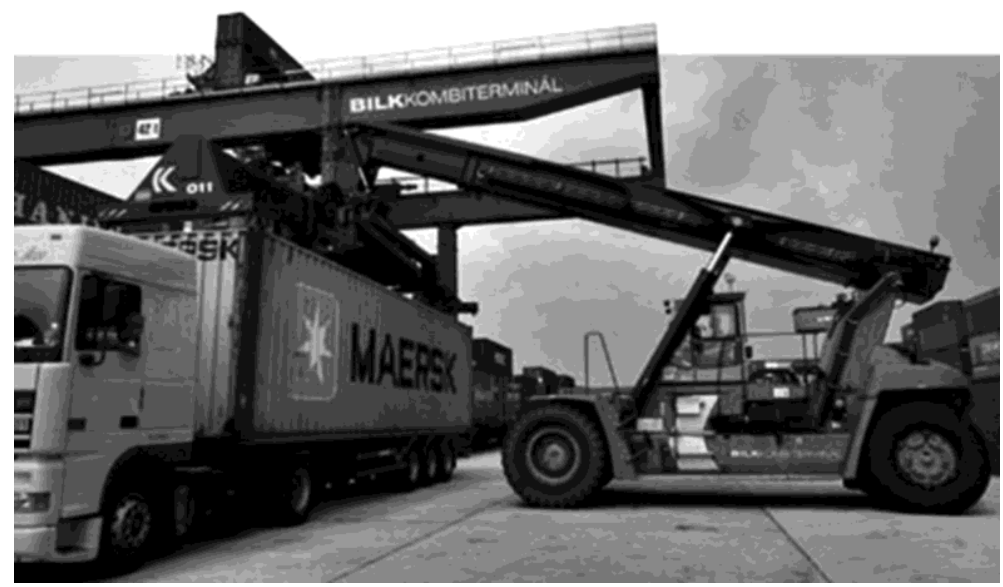

Picture 3. Kalmar loader during operation. [3]

\section{Risk Analysis of Combiterminals}

It is a common characteristic of combiterminals that dangerous goods might be present in their territory at any time in line with the current market demands, however, the time of presence is very short; in many cases the transfer takes place immediately (within some hours), but usually in 1-3 days. A direct activity (repackaging, mixing, solution, dilution, chemical reaction, etc.) involving dangerous substances is not carried out in the territory of combiterminals, therefore the certified packaging of dangerous goods is not removed.

In the territory of combiterminals the dangerous substance might be released basically in two ways:

- in case of catastrophic damage to the packaging, by an instant release of the dangerous substance (catastrophic breakage of packaging);

- in case of a less tightness of packaging, by continuous release.

To present an example, with the help of Det Norske Veritas Phast consequence analyzing software, we show the toxic consequences resulting from the catastrophic damage of a 25-ton acrylonitrile $(\mathrm{ACN})$ transport container.

The below figure indicates the variation of probability of fatality depending on the distance (from the container). 


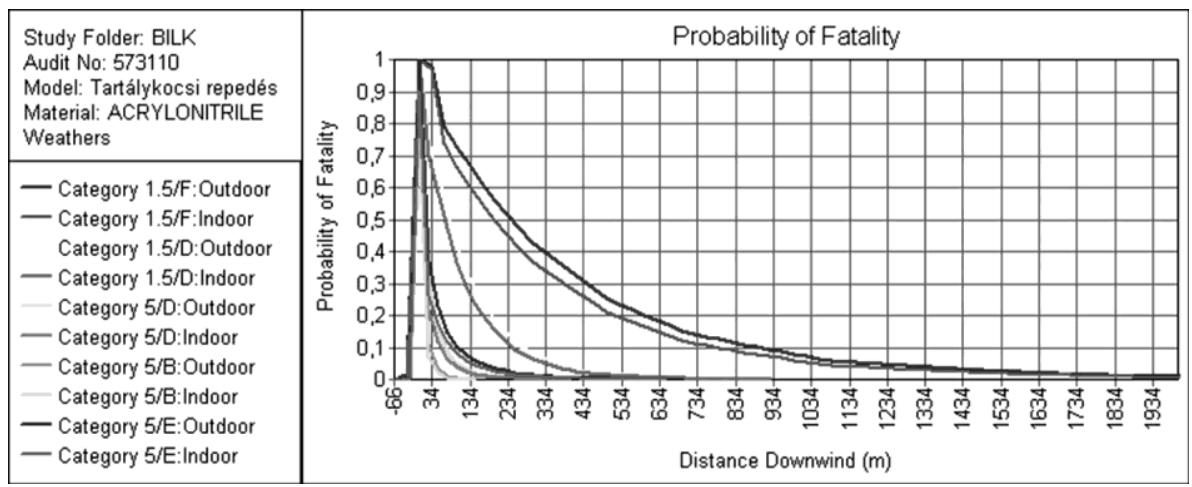

Graph 1. Probability of fatality in relation to distance. [5]

Based on the below figure for persons outside the $1,685 \mathrm{~m}$ area the probability of fatality is less than $1 \%$.
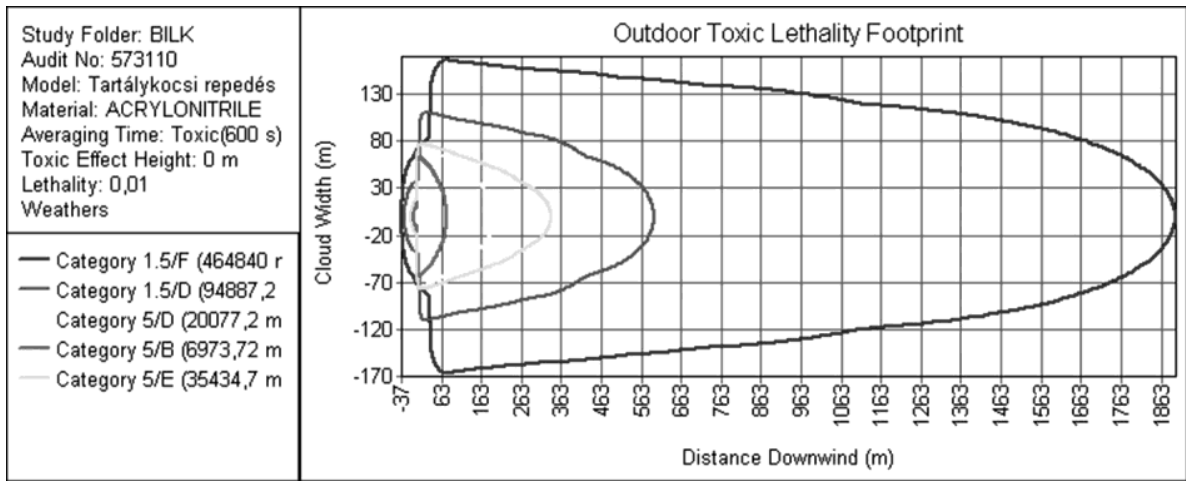

Graph 2. $1 \%$ probability of fatality of persons outside, depending on distance. [5]

Based on the figures, in case of damage to the dangerous goods cargo the fatal consequences might also extend outside the combiterminal, and concentration values might be considered in a greater $\mathrm{km}$ distance which could lead to human injuries.

To analyse the possible external causes of the release of dangerous substances we applied the method of fault tree analysis. Fault tree analysis is a "reverse logic technique", which, after the definition of the unwanted event, determines its basic causes and their combinations with the application of logic relations. The fault tree analysis basically consists of the following 4 steps:

1. Definition of the problem (top event).

2. Creation of the fault tree.

3. Solution of the fault tree (determination of the fault event combinations).

4. Grading the fault event combinations. [6] [7] 
We define "Dangerous substance accident affecting the civil population" as a top event. Based on the experiences in combiterminals operating in Hungary, we created the fault tree shown in Figure 1, below.

The following three simultaneous conditions have to be met in order for a dangerous substance accident affecting the civil population to happen:

- An accident takes place resulting in the release of a dangerous substance (catastrophic damage of the dangerous goods cargo or the substance flowing).

- The safety system serving for damage control purposes does not work properly.

- There is an inhabited area in the surroundings of the combined terminal.

The catastrophic damage of the dangerous goods cargo can be caused by:

- Damage of the lifting engine (Kalmar loader, crane) during the conveyance of materials (e.g. the revolving structure loosens (Event1) or human error (Event2).

- Fall of the dangerous cargo during storage (Event3, Event4).

- External force during storage (e.g. the Kalmar loader reverses against the dangerous goods cargo) (Event5).

The flow of the dangerous goods cargo can be caused by:

- Technical failure of the packaging (container) (e.g. the extracting stud does not close properly) (Event1) and the failure of check-up (Event6, Event7).

- External force (e.g. the Kalmar loader reverses/hits against the dangerous goods cargo and holes it) (Event8).

The improper operation of safety system serving for damage control purposes can be caused by:

- There is no safety planning; the Operator is not prepared for the management of such events (Event9).

- The Operator is prepared for the damage control on the level of safety infrastructure, but the safety equipment is not used, because:

- The event is not noticed or it is recognized too late.

- The protectiveness of safety equipment is under-planned or insufficient.

- The concerned persons are not able to use the safety equipment, lack of training and practice.

The revealed basic events, i.e. the causes triggering the occurrence of the top event can basically be traced back to the deficiencies of the management system. 


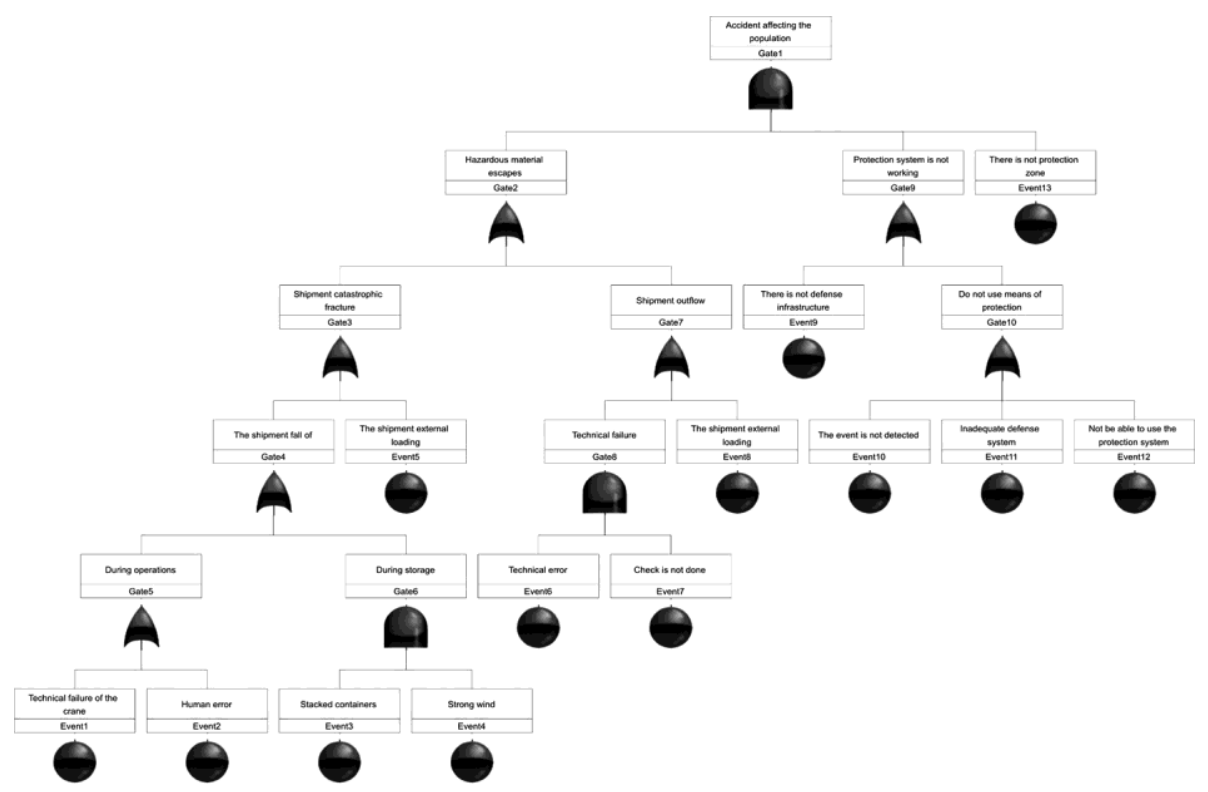

Figure 1. Fault tree: Dangerous substance accident with consequences also outside the combiterminals. [5]

As the above fault tree analysis indicates, in case of combiterminals the causes triggering the occurrence of the top event can generally be traced back to the deficiencies of the management system. The frequency of the top event can be reduced if we reduce the probability and/or frequency of the revealed basic events, which finally entail the top event itself. Such measures reducing the basic events should be included in some internal regulations (as part of the operator's management system).

The extent of consequences in case of an accident can be reduced by safety planning based on hazard analysis. In the frame of safety planning it is necessary to determine the exact measures to be carried out in case of accidents involving dangerous substances as well as the human and material resources required to carry out such measures. The special training of the personnel involved in the safety interventions should also be part of the safety planning, which should be tested by practical exercises. The safety planning should be treated as part of the management system, and as such the results should be included in an internal regulation.

\section{Risk Reducing Tools Applicable in Case of Combiterminals}

Considering the characteristics of combiterminals, i.e. that the present types and quantities of dangerous substances are continuously changing, we recommend the following three effective technical solutions be considered in the course of safety planning.

\section{Water shield}

A water shield is a special thrust nozzle with a standard Storz-clip usually made of aluminium. A vertical metal plate is joined to the horizontal entering pipe, with a special split between the metal plate and the pipe. Through this split the water streams freely form a water curtain 
in the shape of a peacock tail. The water shields have to be set 5-10 $\mathrm{m}$ far from the exit point and also take into consideration the wind direction, so that the explosive gas cloud is directed towards the water curtain. No gas can pass the water curtain without mixing; therefore, the water shields have to be set in a way that the neighbouring water curtains overlap but do not collide with each other. Water shields set this way form a contiguous water wall. Usually a single water shield is not enough for efficient protection, as a high amount of escaping gas can pass by the two sides of the water shield. To prevent such a case, it is recommended to set more water shields in a $\mathrm{V}$ or $\mathrm{U}$ form to demarcate the gas cloud. [8]

The water shield is relatively cheap; it is easy to set up, so it can be used as a mobile tool, or it can be set as a fix structure sparing the installation time, and as such increasing the efficiency of protection. The disadvantage of water shields is that they cannot be used against dangerous substances reacting with water.

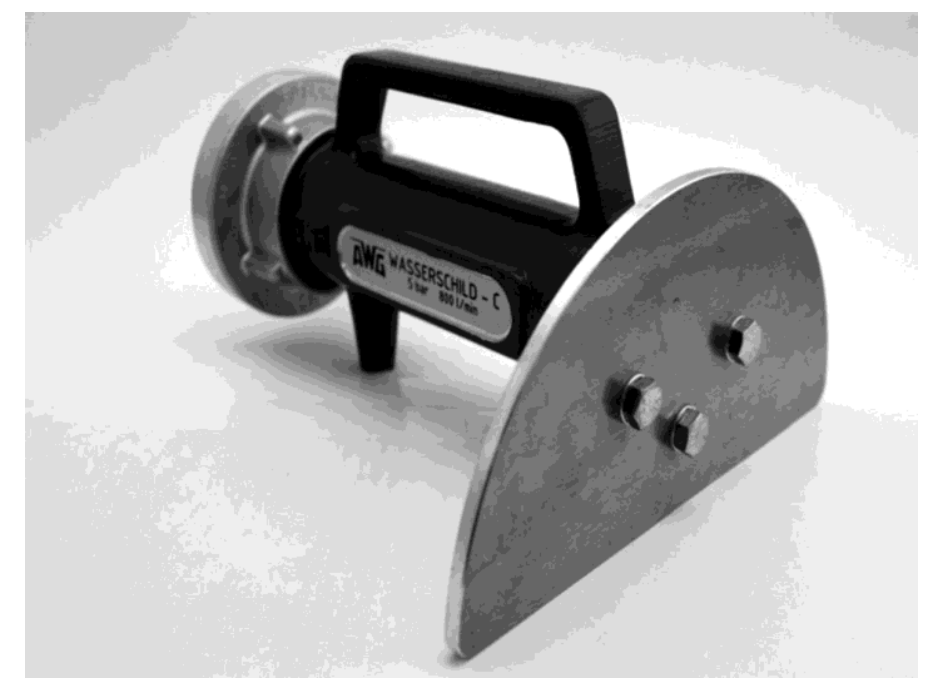

Picture 4. Water shield. [9]

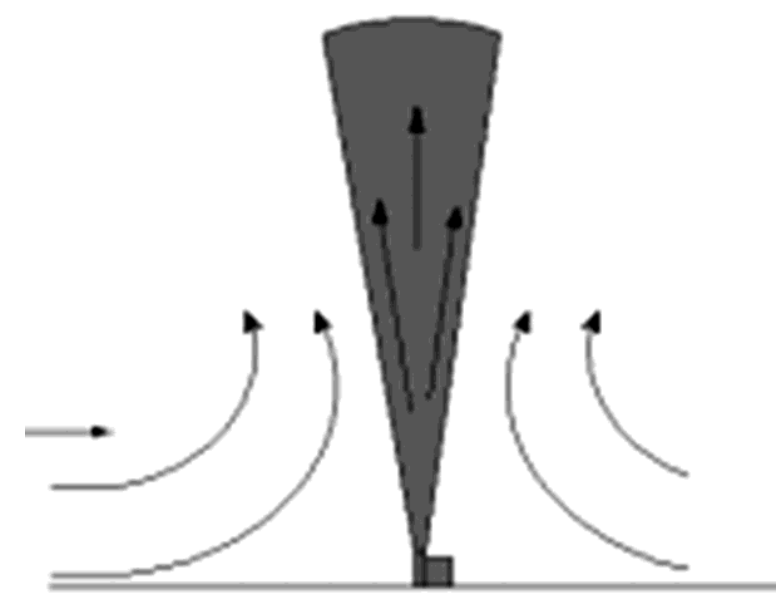

Figure 2. The section of a water shield-profile. [8] 


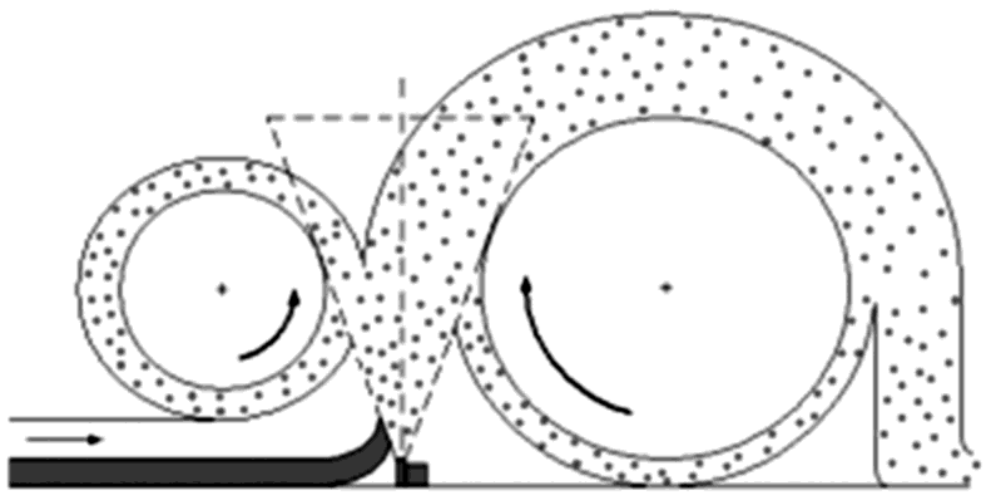

Figure 3. Streams developed around the water shield. [8]

\section{Mobile safety bund}

In case of accidents involving dangerous substances the extent of liquid flows can be reduced by applying mobile safety bunds. The mobile bund is a metal structure, on top of which the damaged container can be placed, so that it takes up the leaking substance. The substance getting into the bund can be extracted into an empty container either by gravity or by a pump. The installation of a mobile safety bund is more expensive than a water shield.

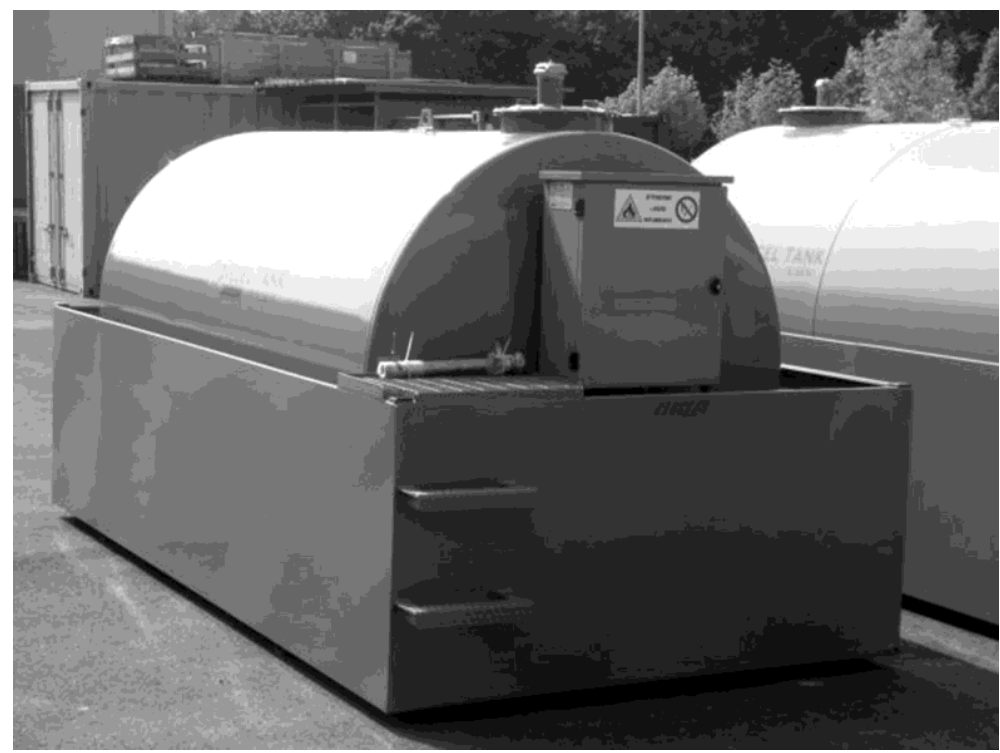

Picture 5. Mobile safety bund. [10] 


\section{Safety bund connected to an underground collecting system}

The storage of dangerous substances can take place in a separate area, which can also function as a safety bund. The storage area has a concrete base covered with an acid-proof, chemical-resistant plastic layer. Its slope ensures the conduct of any potential dangerous substances and rain water into the metal barred drain hole. The liquid is channelled from the drain hole into the underground safety bund with a capacity at least 1.5 times the capacity of the container. The content of the safety bund can be emptied by opening/closing a gate valve.

The installation of the system is expensive; however, due to its very high efficiency the release of dangerous substances through an evaporating pool surface can be minimized.

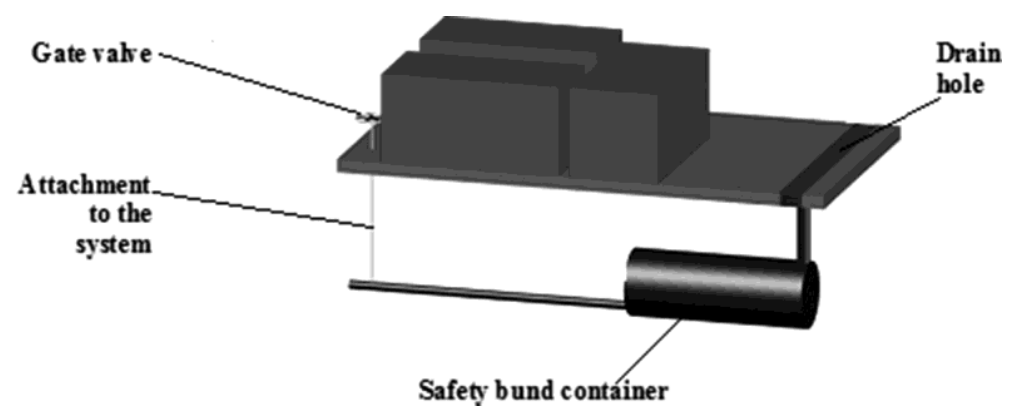

Figure 4. Bund connected to an underground collecting system. [11]

\section{Summary}

In the course of the combined transport of dangerous goods the movement/reload of the cargo from one vehicle to another takes place in combiterminals.

It is a common characteristic of combiterminals that any dangerous goods might be present in their territory at any time, however, the time of presence is very short; in many cases the transfer takes place immediately (within one day), but usually a 1-3-day long transfer should be considered.

Based on the hazard analysis it can be concluded, that accidents involving dangerous substances could happen in the territory of combiterminals, which might have an effect even outside the territory of the combiterminal and affect the civilian population as well.

In our opinion, operators of combiterminals, even if they do not fall under the scope of legal regulations on control of major-accidents involving dangerous substances, should implement the conditions of response to accidents involving dangerous substances in their management systems, and they should have efficient technical tools to reduce the potentially damaging consequences. 
CIMER Zsolt, VARGA Ferenc: Application of Special Risk Reduction Protective Measures...

\section{References}

[1] PREZENSZKI J.: Logistics I. 11 $1^{\text {th }}$ Edition, Budapest: BME Institute of Post-Graduate Engineering, 2003.

[2] ARNOLD B.: Centres of logistics. Hobbivasút, 04 2011. www.hobbivasut.hu/cikkek/a logisztika_kozpontjai.html (downloaded: 0603 2015)

[3] Website of Rail Cargo Terminal. www.railcargobilk.hu/index.php?lang=hu (downloaded: 1903 2015)

[4] SUPPLY CHAIN MONITOR: Special tools. April 2009. www.scmonitor.hu/ archivum/2009/2009-aprilis-specialis-eszkozok (downloaded: 0603 2015)

[5] SZAKÁL B., CIMER Zs.: Control of major-accidents involving dangerous substances relating to combined terminals: The science for population protection. Lázně Bohdaneč: Generalní Reditelství Hasického Sboru CR., 2015.

[6] BOGNÁR B. et al. (Eds.): Industrial Safety I. Handbook on Implementation Tasks of Operators and Authorities. (Iparbiztonságtan I.: Kézikönyv az iparbiztonsági üzemeltetői és hatósági feladatok ellátásához.) Budapest: Nemzeti Közszolgálati és Tankönyvkiadó, 2013.

[7] SZAKÁL B. et al.: Industrial Safety I. Dangerous Substances and their Major Accidents in Industry and Transportation. (Iparbiztonság I. veszélyes anyagok és súlyos baleseteik az iparban és a szállításban.) Budapest: Korytrade Kft., 2012.

[8] VERES R.: The recent means of protection against explosive gas cloud of chemical industry. Pécs: Pécsi Tudományegyetem, 2008. (Dissertation)

[9] Website of Szolgálatiruha.hu Company Introduction www.facebook.com/szolgalatiruha.hu/ photos/a (downloaded: 1903 2015)

[10] Website of Agrotec Magyarország Kft., Company Introduction. www.agrotec.hu (downloaded: 1903 2015)

[11] MAJOROS E.: The possibilities of reducing hazards caused by combined terminals. Budapest: Budapesti Müszaki és Gazdaságtudományi Egyetem, 2015. (Dissertation) 